\title{
The Relationship Between People-Related Elements of Total Quality Management (TQM) Practices and Employees' Job Satisfaction in Apparel Industry in Gampaha District
}

\author{
D.M.T.D. Dissanayake ${ }^{1}$ \& K.G.K.S. Wijesingha ${ }^{2}$ \\ ${ }^{1,2}$ Department of Business Management \\ Faculty of Business Studies \& Finance \\ Wayamba University of Sri Lanka \\ Kuliyapitiya \\ SRI LANKA \\ $\underline{\text { tanyad@wyb.ac.lk }}{ }^{1}, \underline{\text { ksriwije@gmail.com }}{ }^{2}$
}

\begin{abstract}
Apparel manufacturing sector is the largest industrial sector in terms of density of employees. Over the last few decades, the importance of TQM has emphasized as a mean of competitive advantage. Peo in apparel industry. people-related TQM practices (PRTQM) have identified as the most important practices for organizational success. People- related practices mainly involve with soft performance of the organization. Therefore, the focus of the present study is to examine the relationship between people-related elements of Total Quality Management practices and Employees' Job satisfaction in Apparel Industry in Gampaha District, Sri Lanka. In Sri Lanka, the data were collected from 110 employees using convenience sampling technique from Production Managers and Supervisors in selected garment factories in Gampaha district with $94 \%$ response rate. The study finds a positive relationship between people- related TQM practices and employees' job satisfaction. Among six independent variables, Top Management Leadership, Employee Empowerment, Employee Involvement, Teamwork and Compensation had the significant relationship with employees' job satisfaction. The results of this study show that Employee Training has no significant relationship with employees' satisfaction. Finally, the study concludes that, only five TQM elements (Top Management Leadership, Employee Empowerment, Employee Involvement, Teamwork and Compensation) could impact on employee satisfaction in the apparel industry.
\end{abstract}

Keywords: People- related TQM Practices, Job Satisfaction, Apparel industry

\section{INTRODUCTION}

Organizational workforces perform vital role in executing organizational strategies (Lillly \& Maheshwari
2014). Therefore, committed employees in an organization may consider as an asset to that organization in achieving organizational success. Further, 
"employee satisfaction" has considered as one of the important determinants of employees ${ }^{\text {ee }}$ commitment level (Ko \& Boo 2004, Ofoegbu \& Joseph 2013) along with employee attitude and commitment.

According to Lilly \& Maheshwari (2014), satisfied employees lead to great performance in any type of organization. Jha \& Kumar, 2012 stated that employees ${ }^{\text {ee }}$ negative feelings may lead to behaviors that harmful to the organization while the employee satisfaction influences on important aspects of the organization such as productivity and success. Therefore, it can be seen the consecutive relationship among employee satisfaction, employee commitment, and organizational performance.

Quality thinking in organizations started with inspection then evolved into quality control, which evolved into quality assurance and then to quality management (Hoyle, 2007).In 1979, Crosby has identified 14 steps of quality improvement includes management commitment, quality improvement teams, employee education, and recognition ( Samuel, 2011). In 1986, Edward Deming also identified similar 14 points for quality management such as leadership, continuous improvement, on the job training, education and self improvement, and put everybody to work (Samuel, 2011).

TQM philosophies and concepts emerged as the organizations which are making their every effort to achieve and maintain competitiveness is increasing day by day (Magd \& Curry 2003). TQM methods and techniques are concerned to be applicable throughout any type of organization (Magd \& Curry 2003). Those techniques are alike useful in organizations engage in manufacturing (Prajogo \& cooper 2010), public services (Amin \& Ahmad, 2015), education (Bradley, Petrescu \& Simmons, 2004), health care, and hospitality industries.

Introduction of TQM methods can adjust and modify organizations ${ }^{\text {ee }}$ work practices and even thinking pattern of mangers (Magd \& Curry 2003). There are uncertainties in empirical researches about the TQM techniques and concepts used in organizations in different countries and sectors. According to Yapa (2012) the techniques used by different researchers to assess the level of TQM implementation in different countries are also different.

As TQM proponent stated, ultimate goal of TQM is customer satisfaction (Prajogo \& cooper, 2010). According to Matzler K, Fuchs and Schubert, (2004) the employees may be treated as internal customers if the product or service delivery chain seen as a system with interrelated and mutually supportive components. In order to satisfy external customers, it is essential to satisfy the internal customers first hence external customer satisfaction cannot be achieved without internal customer (employee) satisfaction (Prajogo \& cooper, 2010).

TQM is a comprehensive quality management philosophy. TQM requires the integration of every person, activity and process within the 
organization (Ahire, Golhar \& Waller, 1996). Different studies suggest that impact of TQM principles on organizational performance (Kumar, et al., 2009), financial performance, and operational performance (Kuruppuarachchi \& Perera, 2010) in the literature (Ahire , Golhar \& Waller, 1996; Hakes, 1991; Garvin \& David, 1988; Hoang, et al., 2006).

\subsection{Research Problem}

Sri Lankan economy comprises with three main sectors such as service, agriculture and industry (Department of census and statistics, Sri Lanka). In the industry sector there are mainly three categories such as manufacturing, mining and quarrying, and electricity, gas and water supply (Department of Census and Statistics, Sri Lanka).

In 2014 highest labour productivity (as measured by GDP per hour worked, in 2002 prices) growth of $8.7 \%$ has observed in the industry sector (Central Bank of Sri Lanka, 2014). These statics show that even with highest density of employees and with the second highest establishments in manufacturing sector, manufacturing of wearing apparel, dressing and dyeing of fur has recorded less value of input and output

The problems arise on why productivity in manufacturing of wearing apparel, dressing and dying of fur is less than manufacturing of food product and beverages despite of the second largest number of establishments and highest density of employees.? Here it arises the problem what affects the productivity of employees in this apparel manufacturing and dyeing industry.

According to Matzler, Fuchs \& Schubert, (2004) employee satisfaction acts as a driver of productivity and an employee with high level of job satisfaction holds positive attitude towards the job. It has been identified that satisfied employees tend to be more productive than an employee who is dissatisfied (Ofoegbu \& Joseph, 2013; Parvin \& Kabir, 2011).

According to Parvin \& Kabir, (2011) "the level of pay and benefits, the perceived fairness of the promotion system within a company, the quality of the working conditions, leadership and social relationships, and the job itself determines the employee job satisfaction. Other influences on satisfaction such as management style and culture, employee involvement, empowerment, and autonomous workgroups (Amin \& Ahmad, 2015; Prajogo \& cooper, 2010).

Previous literature proves that, job satisfaction resulting from TQM implementation will lead to a greater commitment in adopting TQM programs and producing intended results, high quality performance (Lam, 1996). Therefore, one of the 
roles of the 'soft' TQM factors is to create an environment where the 'hard' TQM can be implemented by empowering and supporting employees to maximize their potential in contributing to the achievement of high quality outcomes of their work (Rahman and Bullock, 2002).

The arguments suggesting a link between people-related TQM practices and job satisfaction have been discussed in the literature with several of them being highlighted below (Ahire et al., 1996; Anderson et al., 1995; Black and Porter, 1996).

Job satisfaction is identified as the main construct which effects on employees' commitment level, which leads to the productivity of the human resource. There is a shortage of adequate empirical findings in the area of TQM, to ensure the impact of PRTQM practices on employees' job satisfaction (Boon, Arumugam, Safa, \& Bakar, 2006; Amin \& Ahmad, 2015). Therefore, there is an empirical gap in the present study.

So, with the previous literature the problem has been clearly depicted as the PRTQM practices were identified and tested in many contexts and also in the appeal industry. The scope was tested in the Sri Lankan context as well and the findings of Chathurika et al, 2016 also proved that there a significant impact of PRTQM practices on job satisfaction. Therefore, there is a research gap between PRTQM and job satisfaction in the context of appeal industry.

\subsection{Research Objectives}

General objective of this study is to identify the relationship of the peoplerelated TQM practices on employee job satisfaction in apparel sector in Gampaha District of Sri Lanka. In order to achieve that broader objective following specific sub objectives have being identified;

- To find the relationship between leadership and job satisfaction of the employees.

- To find the relationship between compensation on opportunities for teamwork and job satisfaction of the employees.

- To find the relationship between employee involvement and job satisfaction of the employees.

- To find the relationship between employee empowerment and job satisfaction of the employees.

- To find the relationship between training and job satisfaction of the employees.

- To find the relationship between Teamwork and job satisfaction of the employees.

\subsection{Literature Review}

\section{Employee job satisfaction}

Employee job satisfaction can be defined as "a pleasurable or positive emotional state resulting from the appraisal of one's job experience" (Locke cited in Saiyadain,2003). It is a feeling consists of employee's cognitive, affective and evaluative reactions to their jobs (Saiyadain, 
2003). According to the above literature employee satisfaction may simply define as emotional state within employees influenced by and to employees ${ }^{\text {ee }}$ job experience (Ofoegbu \& Joseph , 2013). Maintaining a loyal workforce is a qualification for a successful TQM implementation (Changa et al, 2010).

The growing interest on employee satisfaction has led to the studies about antecedence and the consequence in TQM literature (Matzler, Fuchs \& Schubert, 2004). Parvin \& Kabir , 2011 have studied about the factors like working condition, pay and promotion, job security, relation with co-workers, and relation with supervisors. Khuong \& Tien, 2013 have studied supervisor's support, working environment, training, fringe benefit and teamwork as important contributing factors for employees ${ }^{\text {ee }}$ job satisfaction. Those studies have commonly suggested determinants such as: leadership, training and development, employee participation, reward and recognition, customer focus, empowerment, team work, and communication as management practices recognized in the area of Human Resource Management (HRM) practices (Boon, et al, 2006) as determinants of employee satisfaction.

In this study, the discussion of peoplerelated TQM practices is based on an enhanced version of Prajogo and Cooper's (2009) identification of TQM key practices that sustain an organization's business strategy towards job satisfaction. Thus, the six people-related TQM practices selected in relation to employee satisfaction leadership, training, employee empowerment, employee involvement, teamwork, and Compensation.

\section{People-related TQM practices}

Several authors categorized TQM elements into two discrete groups, that is, soft TQM and hard TQM (Vouzas and Psyhogios, 2007; Lau and Idris, 2001; Wilkinson et al., 1994). Hard TQM refers to the various quality tools and techniques whereas the soft aspects emphasize the management of human resources (Wilkinson et al., 1994). In other words, the soft aspects deal mainly with people. Luthans (1995) defined TQM as a participative system whereby all employees are empowered to take responsibility and contribute towards quality management in the organization.

In the pursuit for organizational excellence, TQM captures the quintessence of the people-related practices such as teamwork, employee empowerment and involvement, extensive training, management commitment, as well as reward and recognition to be implemented together with its quality improvement tools and techniques (Yue et al, 2002). Fotopoulos and Psomas (2009) noted that both soft and hard TQM elements have varied impact on the quality management results and they opined that quality improvement is influenced primarily by soft TQM elements and secondarily by hard TQM elements. Brah et.al., (2000) found that intangible features such as top management support, teamwork, employee empowerment and employee involvement, play a significant role in ensuring success of 
TQM in improving company's performance.

This underscores the importance of analyzing the soft elements, more accurately, the people-related practices of TQM. Morrison and Rahim (1993) and Hoogervorst et al. (2005) noted succinctly that effective management of human resources is the core ingredient of success in TQM. This statement is further supported by both Yang (2006) and Jimenez and Costa (2009) whose empirical research revealed that synergy between HRM and TQM practices yielded positive tangible and intangible results

\section{Top management leadership}

Leadership is considered as the preliminary step (Prajogo \& Cooper,2010) and critical ingredient (Chang, Chiu,\& Chen, 2010) before an organization starts with putting TQM in implementation because the right tools and the right systems to do a good job by employees can be supplied only by management (Pekar, 1995).Managers of all layers of the organization must be committed to quality improvement(Pekar, 1995) and that must be visible(Ahire, Golhar, \& Waller, 1996). In previous studies the role of top management in providing leadership had received a great deal of attention (Changa et al, 2010) and the strong relationship between leadership behavior and employees $^{\text {ee }}$ job satisfaction has empirically identified (Prajogo \& cooper, 2010)

\section{Employee Training}

Importance of training is highlighted, unless employees have received formal and systematic training in quality management, other TQM elements such as; employee empowerment and involvement would not be effective (Ahire, Golhar, \& Waller, 1996).Training is a valuable source for employee to expand their knowledge and skills to engage team work for the efficient manner (Changaeat al, 2010). Training can be indifferent forms such as; on the job training or information can be provided to employees about educational programs available in professional institutions (Pekar, 1995).The positive and significant impact of training on employees' job satisfaction has been identified in the literature (Boon,Arumugam, \& Hwa, 2005; Prajogo \&Cooper, 2010). The growing interest in employee satisfaction has led to the studies about the antecedents and consequences in TQM literature (Matzler,Fuchs, \& Schubert, 2004).

The related studies have emphasized the factors contributing to employees' job satisfaction such as; training and development,

leadership, teamwork, pay and promotion, employee participation, employee empowerment as management practices recognized in the area of HRM (Boon, Arumugam, \& Hwa, 2005; Parvin \& Kabir, 2011; Khuong \& Tien, 2013) and TQM lterature (Chang, Chiu, \& Chen, 2010; Amin \& Ahmad, 2015; Ahire, Golhar, \& Waller, 1996). So, based on the literature following variables were 
used for the present study to denote the independent variable.

\section{Employee involvement}

Employee involvement or participation in quality improvement is central and this requires developing both top-down and bottom-up communication channels, providing a mechanism for employees, give their concerns and suggestions on quality issues and direct participation in the decision making process (Prajogo \& Cooper, 2010). Organizations can develop formal systems to encourage, track, and reward employee involvement but, if the extent and quality of participation declines, it may lead to dissatisfaction of the workforce (Ahire, Golhar, \& Waller, 1996)

\section{Employee Empowerment}

TQM proponents and scholars have been made that the empowerment as one of the key elements of TQM and without it continuous improvement will become impossible (Prajogo \& Cooper, 2010). One of the key elements of TQM is employee empowerment involves encouraging employees to respond to quality related problems and it also requires supply them with the resources and authority to do so (Prajogo \& Cooper, 2010). In previous studies it has been empirically supported the strong positive relationship between empowerment and job satisfaction (Prajogo \& Cooper, 2010).

\section{Teamwork}

Teamwork takes place in various forms such as; quality control circles
(QCC) and quality improvement teams (Prajogo \& Cooper,2010). Working as a team leads to better employee attitude and supportive relationship between members facilitates the work (Alsughayir, 2014). Because working as a team leads to better employee attitudes and a supportive relationship between members facilitate the work (Alsughayir, 2014). Team achievements of established goals should be recognized (Pekar P \& Jach, 1995).

\section{METHODS}

In this study conceptual framework designed to find out impact of people related elements of TQM on employees' job satisfaction.

\subsection{Conceptual Framework}

Conceptual framework has been developed by using theoretical perspectives and literature those has being mentioned previously.

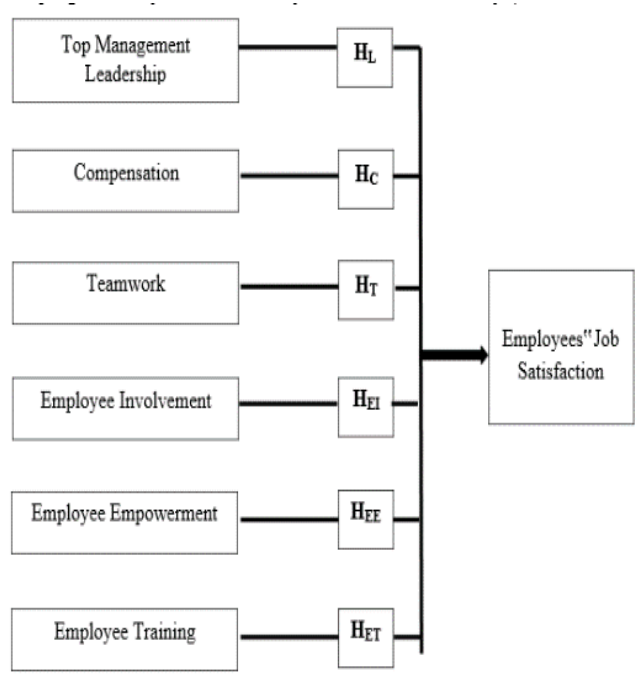

Figure 1. Conceptual Framework 
As per the model there are 6 independent variables (Top Management Leadership, Employee Empowerment, Employee Involvement, Teamwork and Compensation, Training) to measure the relationship with dependent variable (Employee Job satisfaction). Accordingly, 6 hypotheses were developed in order to measure the relationships.

There's a significant relationship between leadership and job satisfaction of the employees.

There's a significant relationship between compensation on opportunities for teamwork and job satisfaction of the employees.

There's a significant relationship between employee involvement and job satisfaction of the employees.

There's a significant relationship between employee empowerment and job satisfaction of the employees.

There's a significant relationship between training and job satisfaction of the employees.

There's a significant relationship between Teamwork and job satisfaction of the employees.

In this study, primary data were collected by using structured questionnaire. Population of this study were Production Managers and Supervisors in Apparel Industry in Gampaha district and sample include one hundred and ten number of employees which has been carefully chosen from the selected apparel factories in Gampaha district. The study used Reliability test to check internal consistency of the component and validity test to check validity of the study and descriptive analysis such as mean, standard deviation, percentage and frequency and correlation analysis was carried out to examine the relationship between the dependent variable

\section{RESULTS}

All variables were measured with questions adapted from existing scales. All items were measured on a five-point Likert-type scale where $1=$ strongly disagree and $5=$ strongly agree.

In this study majority (71.84\%) of respondent were male. Majorities $(54.4 \%)$ of respondent were in $26-35$ age category, $94 \%$ employees were work as permanent employees, $47.6 \%$ of respondents had 1-3 years of experience in current job position, $45.6 \%$ had experience in current field of $1-3$ years and $45.5 \%$ had $1-3$ years of experience in current company.

\section{Normality Test}

Kaiser-Meyer-Olkin (KMO) test is a measure of how suited the data is for factor analysis. The test measures sampling adequacy for each variable in the model and for the complete model. The lower the proportion, the more suited the data is to factor analysis. KMO returns values between 0 and 1 . KMO value more than 0.5 generally indicates that factor analysis is useful. 
Table 1. KMO and Bartlett's Test

\begin{tabular}{|cl|r|}
\hline Kaiser-Meyer-Olkin Measure of Sampling & .789 \\
Bartlett's Test of Sphericity & Approx. Chi- & 207.753 \\
& $\tilde{\text { Df }}$ & 21 \\
& Sig. & .000 \\
\hline
\end{tabular}

Source: Survey Data

This table shows KMO value of 0.789 for the complete model of this study. This indicates that factor analysis is useful with the data collected.

\section{Reliability Analysis}

As Table 3.1 illustrates, all six TQM variables and job satisfaction are measured by their corresponding items. The alpha coefficient for all six TQM elements is approximately greater than 0.7 . These results suggest that items of variables have relatively high internal consistency.

Table 2. Cronbach's alpha coefficient

\begin{tabular}{lcc}
\multicolumn{1}{c}{ Variable } & Alpha value & Number of items \\
\hline Leadership & 0.815 & 11 \\
Employee training & 0.730 & 5 \\
Employee empowerment & 0.703 & 2 \\
Employee involvement & 0.719 & 4 \\
Teamwork & 0.740 & 2 \\
Compensation & 0.741 & 3 \\
Job satisfaction & 0.757 & 5 \\
\hline
\end{tabular}

Source: Survey Data

\section{Correlation Analysis}

Table 3. Correlation between dependent and independent variables

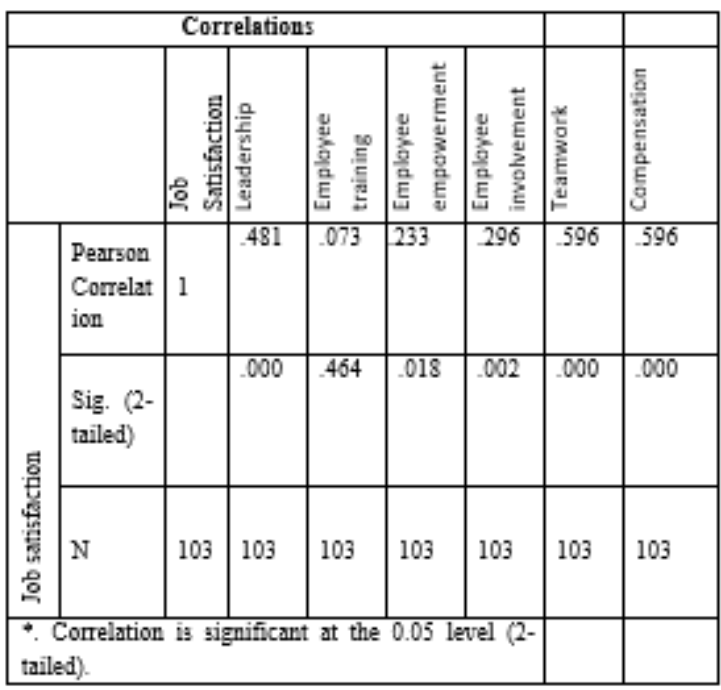

Source: Survey data

According to the results obtained from the correlation analysis here researcher has found that all independent variables are significant at 0.01 levels. But According to the data, only five independent variables, Leadership, Employee empowerment, Employee involvement, Teamwork \& Compensation has $\mathrm{P}$ - values less than 0.05 . And out of those 05 variables Teamwork and Compensation had the highest Correlation values respectively. 
If $\mathrm{P}$ value of independent variable is lower than 0.05 then null hypotheses should be rejected and alternative hypothesis should be accepted. Accordingly, $\mathrm{P}$ value of Top Management Leadership, Employee Training, Employee Empowerment, Employee Involvement, Teamwork and Compensation are 0.000, 0.464, $0.018, \quad 0.002, \quad 0.000$ and 0.000 respectively. Alternative hypothesis of 05 variables other than Employee Training is accepted.

If Pearson coefficient of correlation is close to $1(>0.5)$ there is low positive correlation between independent \&dependent variable. Accordingly, there is low positive correlation between Top Management Leadership and Employee' Job Satisfaction as 0.481. There is low positive correlation between Employee Empowerment and Employees' Job Satisfaction as 0.233 . There is low positive relationship between Employee Involvement and Employees' Job Satisfaction as 0.296. There is high positive relationship between Teamwork and Employees' Job Satisfaction as 0.596. There is High positive relationship between Compensation and Employees' Job Satisfaction as 0.543 .

\section{Hypothesis Testing}

Correlation analysis is a statistical technique which can use to show the relationship between variables. Most common methods that can use for measuring the correlation are Perarson $\&$ Product-moment correlation. This study has mainly used Pesrson correlation for analyze the data and hypotheses.

The Pearson correlation value for top management leadership and Employee job satisfaction is 0.481 and it has a moderate positive relationship. Hence the significance value is less than $0.05(.000<0.05)$. H1 is accepted. The Pearson correlation value for employee training and Employee job satisfaction is 0.73 The significance value is greater than $0.05(.464>0.05)$. therefore, $\mathrm{H} 2$ rejected an it says there's no significant relationship between employee training and Employee job satisfaction. Employee empowerment and Employee job satisfaction has a moderate positive relationship $(\beta=.233)$ and $\mathrm{H} 3$ can be accepted because of the significance value is less than the alpha value.

The Pearson correlation value for employee involvement is 0.296 . It has a moderate positive relationship. The alpha value is less than the significance value (.002>0.05). So, H4 is accepted. Teamwork and Employee job satisfaction has a moderate positive relationship $(\beta=.596)$ and $\mathrm{H} 5$ can be accepted because of the significance value is less than the alpha value $(.000>0.05)$. The Peasorn correlation value for compensation is 0.596. It has a moderate positive relationship. The alpha value is less 
than the significance value (.000>0.05). So, H6 is accepted.

\section{DISCUSSION}

This present study was investigated the Relationship between PeopleRelated elements of Total Quality Management (TQM) Practices and

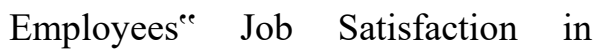
Apparel Manufacturing Industry in Gampaha District. The finding of the present study will be important as it help to solve current Employees" Job Satisfaction problem. Similar studies have been conducted in Australia (Prajogo \& Cooper, 2010),Pakistan (Amin \& Ahmad, 2015), Saudi Arabia (Alsughayir, 2014), and India (Jha \&Kumar, 2012).

Based on the reliability analysis all the independent variables are reliable and the Cronbach alfa value for all the independent variable are greater than 0.7. as it shows a higher internal consistency of the variables.

The general objective of this study is to examine the impact of the PRTQM practices on employees' Job Satisfaction. The study considered the impact of quality of the Leadership, employee Training, employee Empowerment, employee Involvement, and Teamwork on the Job Satisfaction as similarto two other previous studies done by Prajogo \& Cooper (2010) and Amin \& Ahmad, (2015).
By applying correlation technique all relationships were found significant except Employee Training. There is strong relationship between Teamwork and Compensation with Employees' Job Satisfaction. Leadership, Employee Empowerment and Employee Involvement relationship have less influence on Employees' Job Satisfaction. Accordingly, Teamwork is the important independent variable among them.

In achieving the objective of measure the strength and significance of the relationship between each PRTQM practice and Job Satisfaction, it was apparent that findings were different from previous studies. The results show significant positive relationships of Leadership, employee, employee Involvement, employee Empowerment, and Teamwork, compensation with the Job Satisfaction. This indicates that the Job Satisfaction is a result of collective practices of PRTQM and when the PRTQM practices are in higher level the Job Satisfaction of the employee will also be high. This finding is supported by the findings of Prajogo \&Cooper (2010). Findings of Alsughayir (2014) also confirmed the strong positive relationship between working as a team (Teamwork) and the Job Satisfaction. 
There were some inconsistencies of the findings with the previous literature. The insignificance of the relationship between (compensation) and Job Satisfaction is found by Amin and Ahmad (2015). The findings of the Prajogo \&Cooper (2010) showed that there as positive relationship between training and job satisfaction but the present study found that there's a negative relationship between training and job satisfaction.

\section{CONCLUSION}

The present study was conducted to find the relationship between people related TQM practices and job satisfaction. In apparel manufacturing organizations ${ }^{\text {ee }}$ the productivity depends on the performance of employees. Therefore, satisfied employee performance is a must to maintain organizational success.

Since it is implicated that Top Management Leadership, Employee Empowerment, Employee Involvement, Teamwork and Compensation has significant impact on satisfaction. Out of these 05 People-Related elements of TQM practices, Teamwork, Compensation and Top management Leadership has the highest impact when comparing with others.

Teamwork has the highest impact (35.5\%) on Employees ${ }^{\text {ee }}$ Job satisfaction. So, the implementation of quality improvement teams, crossfunctional teams and etc. will help organization to increase the employeese $^{\text {ee job satisfaction. Some }}$ techniques such as lean manufacturing also can use to increase the employees ${ }^{\text {ee }}$ job satisfaction.

Compensation has the second highest impact (29.5\%) on Employees ${ }^{\text {ee }}$ Job Satisfaction. Quality based evaluation increase compensation and other rewards will increase the employees ${ }^{\text {ee }}$ job satisfaction.

Top Managers Leadership have 23.1\% impact on Employeese Job Satisfaction. So Top Managers have a critical role in determining employee satisfaction.

Leadership dimensions and employee involvement dimensions such as; clarity of the quality goals, relative importance given to quality as a strategic issue, relative importance given to quality versus cost, relative importance given to quality versus production schedule, allocation of resources to quality improvement efforts, performance evaluation of managers based on quality, encouragement for employees to give suggestions, employee suggestion implementation are recommended to enhance within those organization setting.

There are several limitations of this study. First, it may lack generalizability, due to the sampling technique. The population considered in the study is only the organizations in Gampaha district only. It does not 
necessarily reflect the perception and level of satisfaction of employees in the Apparel manufacturing organizations outside the Gampaha District. Limited availability of previous studies, literature, and figures was another constraint, especially in Sri Lankan context. Therefore, this research is limited to less background knowledge in the area of study. Further research could be conducted considering some other PRTQM practices which are identified in the literature but not considered in this study to examine those relationships with the employees' Job Satisfaction. In addition, it is important to extend the focus on other provinces in Sri Lanka and other industries to generalize the findings.

And there are more factors that is cased to employee job satisfaction within an organization. But here only selected Top Management Leadership, Employee Training, Employee Empowerment, Employee Involvement, Teamwork and Compensation to examine the problem. The failure of TQM programs is attributed to lack of consideration to soft side of TQM by implementing organizations and emphasized teamwork, employee involvement and top management commitment as highly essential to success of TQM strategy (Prajogo and Cooper, 2017).

All TQM practices have not been worked same for all organization.
Therefore, it is important for HR manager to find out what works for their organization. Present study found that Top Management Leadership, Employee Empowerment, Employee Involvement, Teamwork and Compensation were strong TQM practice predictors of Employees' Job Satisfaction. The implication of this finding is that those abovementioned variables are the most critical TQM practices to be implemented by Apparel manufacturing companies to increase Employees' Job Satisfaction.

Since it is implicated that employee involvement and leadership have a significant influence on satisfaction, top managers have a critical role in determining employee satisfaction. Leadership dimensions and employee involvement dimensions such as; clarity of the quality goals, importance given to quality as a strategic issue, allocation of resources to quality improvement efforts, performance evaluation of managers based on quality, encouragement for employees to give suggestions and implementation of them, and framework for evaluating the quality of participation are recommended to enhance within those organization settings. 
All TQM practices have not been worked same for all organization. Therefore, it is important for HR manager to find out what works for their organization. Present study found that Top Management Leadership, Employee Empowerment, Employee Involvement, Teamwork and Compensation were strong TQM practice predictors of Employees ${ }^{\text {ee }} \mathrm{Job}$ Satisfaction. The implication of this finding is that those above-mentioned variables are the most critical TQM practices to be implemented by Apparel manufacturing companies to increase Employees ${ }^{e e}$ Job Satisfaction. Therefore, the recommendations may valid to the apparel industry in Gampaha district.

\section{REFERENCE}

Ahire, S., Golhar, D., \& Waller,A. (1996). Development and Validation of TQM Implementation Constructs. Decision Sciences, 27(1), 23-56)

Alsughayir, A. (2014). Does Practicing Total Quality Management Affect Employee Job Satisfaction in Saudi Arabian Organisations? European Jounral of Business and Management, 6 (3), 169174.

Amin, H., \& Ahmad, B. (2015). The Impact of Soft Total Quality Management Practices on Employees' Job Satisfaction. (pp. 1-20). Riga, Lativia: Riga: University of Latvia.
Boon, K., Arumugam, V., \& Hwa, T. (2005). Does Soft TQM Predict Employees' Attitudes? The TQM Magazine, 17 (3), 279289.

Boon, O., Arumugam, V., Safa, M., \& Bakar, A. (2007). HRM and TQM: Association with Job Involvement. Personnel Review, 36(6), 939-962.

Chang, C, Chiu, C, and Chen, A. (2010). The Effect of TQM Practices on Employee Satisfaction \& Loyalty in Government total quality Management \& Business Excellence, 21(12), 1299-1314.

Department of Census and Statistics, SriLanka. (2015). Annual Survey of Industries-Final Report-2013.Retrieved

November 11, 2015, fromDepartment of Census and Statistics-Sri Lanka: http://www.statistics.gov.lk/

Garvin, David A. (1988), Managing Quality: The Strategic and Competitive Edge, New York: The Free Press.

Hakes, C. (1996) The Corporate SelfAssessment Handbook. 3rd edn. London: Chapman and Hall.

Hoang, D. Igel, B., and Laosirihongthnog, T. (2006). The impact of total quality management on innovation: Findings from a developing country. International Journal of Quality \& Reliability Management, v. 23, n. 9, p. 1092 1117. 
Herzberg F , Mausner B,Peterson R and Capwell D (1957). Job Attitudes: Review of Research and opinion. Psychological service of pittsburgh.

Hoang D, Igel B. (2006). The impact of TQM on innovation. International Journal of Quality and Reliability Management, 1092-1117.

Jha U C and Kumar S. (2012). Effect of TQM on employee satisfaction. Radix International Journal of research in social sciences, 151-221.

Khuong M, and Tien B (2013). Factors influencing employee loyalty directly and indirectly. International Journal of current research and academic review, 81-95.

Kodali M. (2008). TQM implementation element for manufacturing excellence. TQM journal 20, 559-621.

Kuruppuarachchi, D., and Perera, H. (2010). Impact of TQM and technology on operational Performance. The IUP Journal of Operation Management, 9 (3), 2341.

Lilly J and Maheshwari M. (2014). A study on employee satisfaction towards TQM practices. International Journal of Scientific research, 116-118.

Magd, H., and Curry, A. (2003). ISO 9000 and TQM: Are They Complementary or Contradictory to Each Other?
The TQM Magazine, 15(4), 244256.

Matzler, K., Fuchs, M., \& Schubert, A. (2004). Employee Satisfaction: Does Kano's Model Apply? Total Quality Management \& Business Excellence, 15(9-10), 11791198.

Ofoegbu, O., \& Joseph, A. (2013, April). Determinants of Employees Performance in Workplace: A Case Study of Bond Chemical in Oyo State. International Journal of Business and Behavioral Sciences, 3 (4), 218-250.

Pekar, Parvin, M., \& Kabir, M.. (2011, December). Factors Affecting Employees Job Satisfaction of Pharmaceutical Sector. Australian Journal of Business and Management Research, 1 (9), 113-123. J. P. (1995). Total Quality Management: Guiding Principles for Application. Philadelphia: ASTM.

Prajogo, D. and Cooper, B. (2017). The individual and organizational level effects of TQM practices on job satisfaction. International Journal of Manpower, 38(2), 215-225 